\title{
СУЧАСНЕ БАЧЕННЯ СИСТЕМИ ФАХОВОЇ ПІДГОТОВКИ ПЕДАГОГІВ ПРОФЕСІЙНОГО НАВЧАННЯ В УНІВЕРСИТЕТАХ ЯК ПЕДАГОГІЧНӦ̈ МОДЕЛІ
}

\author{
Гуменюк Тетяна Броніславівна, кандидат педагогічних наук, доцент \\ Украӥна, м. Київ, Національний педагогічний університет імені М. П. Драгоманова, \\ завідувач кафедри промислової інженерії та сервісу
}

DOI: https://doi.org/10.31435/rsglobal_ws/30082018/6077

\begin{abstract}
ARTICLE INFO
Received: 10 July 2018

Accepted: 28 August 2018

Published: 30 August 2018

\section{KEYWORDS}

professional training, teacher of professional training, professional and pedagogical education, methodological approaches, modern educational concepts.

ABSTRACT

The article substantiates the modern vision of the system of professional training of teachers of professional education at universities as a pedagogical model. The structural-functional model of professional training on the new conceptual-methodological basis is offered. The purpose of this system is to train a competent specialist capable of pedagogical and engineering activities in institutions of vocational (vocational) education; able to realize itself in the educational sphere, in production and in the sphere of service; a specialist of the future with neo-humanistic views and established ecological culture. It is noted that for the implementation of the system of professional training it is necessary to theoretically substantiate and develop scientific and methodological materials that will enable to introduce author's developments in the practice of professional training of teachers of professional training at universities.
\end{abstract}

Citation: Гуменюк Тетяна Броніславівна. (2018) Suchasne Bachennia Systemy Fakhovoi Pidhotovky Pedahohiv Profesiinoho Navchannia v Universytetakh yak Pedahohichnoi Modeli. World Science. 8(36), Vol.3. doi: 10.31435/rsglobal_ws/30082018/6077

Copyright: (C) 2018 Гуменюк Тетяна Броніславівна. This is an open-access article distributed under the terms of the Creative Commons Attribution License (CC BY). The use, distribution or reproduction in other forums is permitted, provided the original author(s) or licensor are credited and that the original publication in this journal is cited, in accordance with accepted academic practice. No use, distribution or reproduction is permitted which does not comply with these terms.

Вступ. Розвиток ринку праці та ринку робочої сили, мінливі соціально-економічні умови вимагають підготовки фахівців, що володіють не тільки спеціальними знаннями, а й якостями, що забезпечують їх конкурентоспроможність, професійну мобільність, здатність правильно оцінювати цивілізаційні процеси та бути учасниками збереження усього живого на Землі. Це в першу чергу відноситься до системи професійної освіти, яка формує інтелектуальні ресурси суспільства і забезпечує високий рівень якості продуктивних сил.

Перетворення в економіці і професійна освіта взаємопов'язані і не можуть бути ефективно здійснені без розвитку системи підготовки фахівців для закладів професійно-технічної (професійної) освіти. Завдання підготовки таких фахівців - педагогів професійного навчання спільно 3 завданням формування суспільно значущої особистості, здатної розвиватися в процесі своєї професійної діяльності, покликана вирішувати система професійно-педагогічної освіти (ППО).

Проблеми розвитку професійної освіти в цілому та професійно-педагогічної освіти зокрема, досліджені і досліджуються багатьма вітчизняними та зарубіжними вченими. Так, в загальнотеоретичному плані проблеми підготовки педагогів глибоко досліджували Ю. Бабанський, В. Беспалько, Н. Кузьміна, В. Сластьонін, Н. Таланчук, В. Якунін та ін. Фундаментальні розробки в області теорії, філософії і соціології освіти, вивчення особистості педагога, а також навчання проведені В.Андрущенком, В. Беспалько, А. Васильєвою, 
В. Загвязинським, Г. Зборівським, Т. Кудрявцевим та ін. Питання про характер i зміст діяльності професійно-педагогічних працівників, а також проблеми їх підготовки розглядалися в роботах С. Батишева, В. Безрукова, А. Бєляєвої, Г. Зборовського, Е. Зеера, О.Коваленко, I. Кузьміна, В. Ледньова, А. Новикова, Н.Ничкало, О.Щербак та ін. Різні педагогічні та організаційні аспекти управління освітніми системами, трансформації навчальних закладів, розвитку багаторівневої професійної освіти досліджували А. Глазунов, Ю. Конаржевський, М. Кондаков, В. Лазарєв, А. Найн, А. Новиков, А. Орлов, М. Поташник, Е. Ткаченко, П. Третьяков, Л. Федотова, П. Худомінський, Т. Шамова та ін.

Відзначаючи цінність раніше проведених досліджень, можна підкреслити, що теоретичні основи професійно-педагогічної освіти ще недостатньо розроблені, а процес розвитку системи підготовки педагогів професійного навчання, що здійснюється на емпіричній основі, недостатньо ефективний.

Метою статті $\epsilon$ обгрунтування сучасного бачення системи фахової підготовки педагогів професійного навчання в університетах як педагогічної моделі.

Результати дослідження. В даний час в практиці професійно-педагогічної освіти існує низка проблем. Одна 3 них пов'язана 3 недостатністю масштабів системи ППО в Україні для задоволення потреб початкової професійної освіти в педагогічних кадрах. Наслідком $\epsilon$ невідповідність існуючого рівня кваліфікації професійно-педагогічного персоналу, що працює в закладах професійно-технічної (професійної) освіти, потребам людини, суспільства, держави і народного господарства.

Друга проблема визначається недостатньою розвиненістю системи управління процесами становлення, забезпечення і підвищення якості підготовки педагогів професійного навчання в університетах.

Третя - викликана ослабленням державної підтримки підготовки по низці непривабливих для населення, але актуальних для суспільства професій деяких галузей економіки (наприклад, машинобудування, металургії, деревообробки, технологій легкої промисловості та ін.) i відповідних їм професійно-педагогічних спеціалізацій.

Перераховані проблеми багато в чому пов'язані не тільки з розвитком професійнопедагогічної освіти в цілому, але і стосуються проблем, характерних для закладів вищої освіти, які здійснюють підготовку педагогів професійного навчання, і перешкоджають їх розвитку як суб'єктів професійно-педагогічної освіти.

Сьогодні існує об'єктивна необхідність у створенні методологічних та концептуальних основ розвитку професійно-педагогічної освіти, яка в мінливих соціально-економічних i соціально-педагогічних умовах має перейти на якісно новий рівень, стати адекватною до нових умов, забезпечувати розвиток економіки, задовольняти нові запити людини і суспільства.

При цьому суть розвитку професійно-педагогічної освіти як процесу закономірного переходу в більш досконалий стан бачиться не в сукупності заходів, не в руйнуванні існуючих форм підготовки педагогів професійного навчання або приєднання до них нових. Мається на увазі створення цілісної освітньої системи на основі розвитку існуючої іiі бази шляхом реалізації ідей гуманізації, неперервності професійно-педагогічної освіти, принципів системного підходу, концепції випереджаючої освіти, кваліметрії та інших наук.

У зв'язку з цим виділено ключове протиріччя між мінливими цілями та потребами особистості і суспільства в підвищенні ефективності та якості професійно-педагогічної освіти, 3 одного боку, і можливостями системи професійно-педагогічної освіти забезпечити реалізацію даних цілей і потреб у зв'язку 3 недостатньою розробленістю теоретичних основ цілісної системи фахової підготовки педагогічних кадрів для закладів професійно-технічної (професійної) освіти, що забезпечують його ефективний розвиток в сучасних соціальноекономічних умовах, з іншого боку.

Професійно-педагогічна освіта $є$ складною системою, що включає взаємопов'язані компоненти: принципи, цілі, завдання, зміст, засоби, форми, методи і функції. Отже, при вирішенні проблем іiі ефективного розвитку необхідно вивчити дані компоненти, а також принципи організації та управління ними. Такі дослідження важливі для створення основ, що обумовлюють логіку і технологію процесу фахової підготовки педагогів професійного навчання. Зазначені принципи, зміст, методи і технології одночасно стосуються, з одного боку, питань організації системи професійно-педагогічної освіти, а з іншого - питань їі науково-методичного забезпечення. Тому правомірно ставитися до них як до сутності професійно-педагогічної освіти, адекватної запитам особистості, суспільства, держави та економіки, приймати їх вихідними і головними положеннями даного виду освіти і їі методологічними основами. 
Із самого початку передбачається, що система фахової підготовки педагогів професійного навчання забезпечує зв'язок професійно-педагогічної освіти 3 соціальним оточенням (суспільством і системою освіти); створює умови для реалізації педагогічної управлінської діяльності, наукової обгрунтованості змісту освіти, оптимального співвідношення в професійно-педагогічній освіті змісту, форм і методів, теоретичного i практичного, врахування індивідуальних потреб і запитів здобувачів вищої освіти.

Професійно-педагогічна освіта є специфічним видом освіти, що значно відрізняється від інженерно-технічної або тільки педагогічної. Тому, дослідження, спрямоване на розробку системи фахової підготовки педагогів професійного навчання в університетах, є актуальним i практично значимим, оскільки покликане подолати основне ключове протиріччя, конкретизоване наступними протиріччями сучасного стану професійно-педагогічної освіти:

- $\quad$ між зростаючими потребами особистості, суспільства і економіки в професійно-педагогічній освіті та недостатнім масштабом існуючої системи підготовки педагогів професійного навчання;

- між необхідністю забезпечити підготовку висококваліфікованого персоналу для систем початкового i середнього рівня професійної освіти в умовах зміни соціальноекономічного стану країни та можливостями сформованої системи професійно-педагогічної освіти гнучко і швидко реагувати на мінливі умови;

- між зростанням вимог до якості професійної освіти і реалізованими в управлінні професійно-педагогічною освітою автономними, несистемними заходами і одноаспектними підходами, спрямованими на підвищення якості освітніх процесів.

3 огляду на недостатню теоретичну розробленість проблеми фахової підготовки педагогічних кадрів для закладів професійно-технічної (професійної) освіти та їі практичну значущість в сучасних соціально-економічних умовах, нами проведено: дослідження сучасного стану і проблем професійно-педагогічної освіти в Україні, розвиток ППО в країнах СНД і за кордоном; аналіз наукових концепцій професійно-педагогічної освіти в історичному контексті та виявлено фактори, які визначають іiі становлення; дослідження методологічних основ сучасних педагогічних систем та теоретично обгрунтувано системний та компетентністний підходи як умову освітньої інноватики в професійно-педагогічній освіті; розробку концептуальних засад розвитку професійно-педагогічної освіти, які вирішують основні противоріччя в загальному, а також такі що задовольняють систему фахової підготовки педагогів професійного навчання зокрема; теоретичне обгрунтування і розроблено модель системи фахової підготовки педагогів професійного навчання з урахуванням вимог сучасного виробництва та професійно-педагогічної освіти; теоретичне обгрунтування кваліметричного підходу до діагностики фахових компетентностей випускників університетів.

3 огляду на те, що стратегічною метою освітньої системи є фахова підготовка педагогів професійного навчання, з поміж функцій, які має вона виконувати виділені такі: методологічна для уможливлення проектування змісту освіти, значущого для фахової підготовки педагогів професійного навчання; концептуальна - проникнення змісту навчання до структури професійно-орієнтованої діяльності здобувачів вищої освіти.

Концептуально-методологічна основа пропонованої структурно-функціональної моделі системи фахової підготовки педагогів професійного навчання (рис.1) складається 3 трьох блоків: блок концептуальної ідеї; блок основних концептів (методологічний, теоретичний, технологічний, організаційно-процесуальний); блок концепції педагогічної кваліметрії.

Модель даної системи вміщує п'ять основних компоненти: цільовий, змістовий, технологічний, організаційно-процесуальний та діагностично-результативний.

Цільовий компонент системи фахової підготовки педагогів професійного навчання представлено цільовими завданнями, виконання яких дозволяє виконати соціальний запит на фахівця. Це: підготовка компетентного фахівця здатного до професійно(інженерно)педагогічної діяльності у ЗПТ(П)О; підготовка мобільного фахівця здатного реалізувати себе в освітній сфері, на виробництві, у сфері обслуговування; підготовка фахівця майбутнього 3 неогуманістичними поглядами та сформованою екологічною культурою. 


\section{СОЦІАЛЬНИЙ ЗАПИТ}

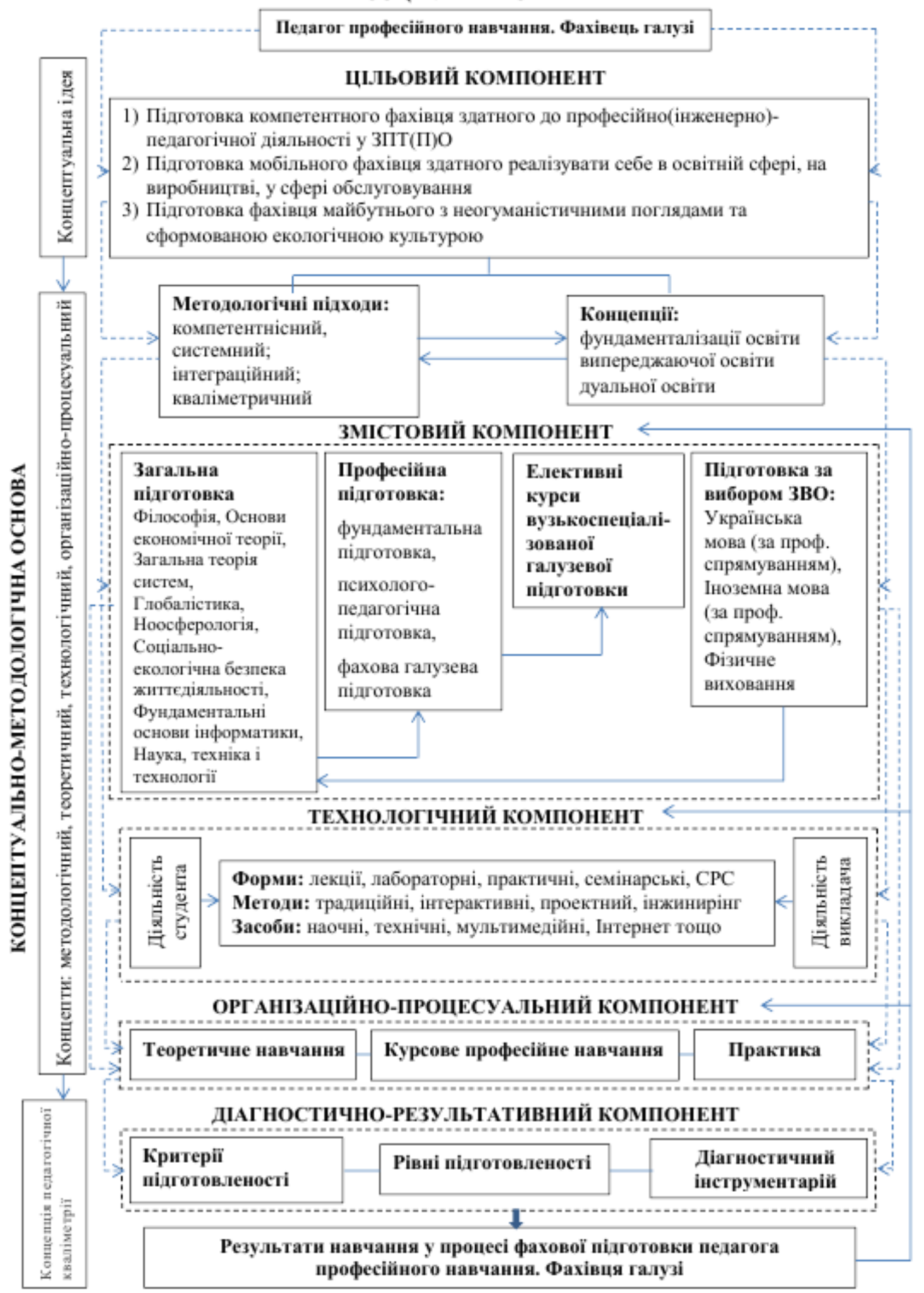

Рис.1 Структурно-функиіональна модель системи фахової підготовки педагогів професійного навчання 
Досягнення цілей видається можливим за умови використання в процесі підготовки методологічних підходів (компетентнісного, системного, інтеграційного, кваліметричного) та реалізації сучасних концепцій освіти (фундаменталізації, випереджаючої, дуальної).

Змістовий компонент системи фахової підготовки педагогів професійного навчання об’єднує чотири складники: навчальні дисципліни загальної підготовки; навчальні дисципліни професійної підготовки (фундаментальна галузева підготовка, психолого-педагогічна підготовка, фахова галузева підготовка); елективні курси вузькоспеціалізованої галузевої підготовки; підготовка за вибором ЗВО.

Дисципліни загальної підготовки носять світоглядний характер i вирішують завдання підготовки фахівця майбутнього [14]. У свою чергу, дисципліни фундаментальної галузевої підготовки забезпечують подалышу фахову галузеву підготовку педагогів професійного навчання, тому для кожної спеціалізації спеціальності 015 Професійна освіта їх перелік різний. До прикладу, для технічних спеціалізацій це природничо-математичні та загальнотехнічні дисципліни $[2,3]$.

Блок психолого-педагогічної підготовки педагогів професійного навчання формується 3 основних наукових дисциплін: «Психологія», «Професійна педагогіка», «Методика професійного навчання», «Е-навчання», які є незмінними і однаковими для усіх спеціалізацій спеціальності 015 Професійна освіта.

Формування фахової галузевої підготовки заслуговує на особливу увагу, так як зміст іiі залежить від бачення здобувача вищої освіти як майбутнього педагога професійного навчання (за спеціалізацією) або випускника ЗВО з подвійною кваліфікацією «Педагог професійного навчання. Фахівець галузі». Ми займаємо позицію подвійної кваліфікації, що забезпечить у майбутньому глибоку фахову галузеву підготовку та дасть можливість фахівцям працювати у відповідній галузі. Тобто, такий підхід забезпечить високу якість професійної освіти робітничих кадрів у ЗПТ(П)О та професійну мобільність випускників ППО ЗВО на ринку праці. Отже, зміст фахової галузевої підготовки педагогів професійного навчання, на нашу думку, повинен повністю відповідати професійній підготовці фахівців відповідної галузі.

Особливість технологічного компоненту розробленої системи фахової підготовки педагогів професійного навчання полягає у визначенні форм, методів та засобів навчання i визначають діяльність викладачів та студентів у процесі навчання зорієнтовану на науковопошукову, проектну діяльність та інжиніринг.

Бєляєв Ю. зазначає, що науково-дослідна діяльність студентів - це діяльність, пов'язана 3 пошуком відповіді на творчу, дослідницьку задачу із заздалегідь невідомим рішенням. Вона включає у себе наступні етапи: постановку проблеми; вивчення теорії, що присвячена означеній проблематиці; добір методик дослідження і практичне оволодіння ними; пошук необхідного матеріалу, його аналіз та узагальнення; власні висновки [1].

У свою чергу, проектування - це особливий тип інтелектуальної діяльності, відмінною особливістю якої є перспективна орієнтація, практично спрямоване дослідження. Суть проектної технології - стимулювати інтерес здобувачів вищої освіти до певних проблем, які передбачають володіння певною сумою знань, та через проектну діяльність, а саме розв'язання однієї або цілої низки проблем показати практичне застосування надбаних знань - від теорії до практики» [4]. Метою проектного навчання є формування таких умов навчального процесу, за яких його результатом стає здобуття індивідуального досвіду проектної діяльності майбутніх фахівців [13].

У чинному законодавстві інжиніринг розглядається як надання послуг і виконання робіт. Зокрема, у Податковому кодексі України від 02.12.2010 р. № 2755-VI у п. 14.1.85 зазначено, що інжиніринг - це "надання послуг (виконання робіт) із складення технічних завдань, проектних пропозицій, проведення наукових досліджень i техніко-економічних обстежень, виконання інженерно-розвідувальних робіт з будівництва об'єктів, розроблення технічної документації, проектування та конструкторського опрацювання об'єктів техніки і технології, надання консультації та авторського нагляду під час монтажних та пусконалагоджувальних робіт, а також надання консультацій, пов'язаних із такими послугами (роботами)". Незважаючи на немалу вартість інжинірингових робіт та послуг (які переважно $\epsilon$ інвестиціями), їхнє використання є здебільшого економічно обгрунтованим, адже знижує рівень ризику реалізації проектів. Змовникам інжинірингових послуг не потрібно контактувати із різними організаціями та особами, адже це бере на себе інжинірингове підприємство.

Отже, на нашу думку серед низки інтерактивних, інноваційних технологій навчання провідне місце має належати саме дослідницько-пошуковій, проектній та інжиніринговій діяльності як послідовних взаємопов'язаних практично-орієнтованих процесів у системі фахової підготовки педагогів професійного навчання. 
Організаційно-процесуальний компонент у свою чергу визначає основні форми організації навчальної діяльності такі як теоретичне навчання, яке проводиться у формі лекцій, лабораторних робіт, практичних та семінарських, а також самостійної роботи студентів; курсове професійне навчання як обов'язковий складник фахової підготовки педагогів професійного навчання, що дає можливість здобувачам вищої освіти отримати робітничу кваліфікацію 3 професії, яка відповідає майбутній професійно-педагогічній діяльності здобувача вищої освіти; практика організована за принципом дуальної форми навчання, яка реалізується шляхом неперервної взаємодії університетів з виробництвом, закладами сфери обслуговування та бізнесом, що виступають базами практик.

Діагностично-результативний компонент системи формується на концепції педагогічної кваліметрії, яка забезпечує визначення якості фахової підготовки педагогів професійного навчання. Даний компонент пронизує увесь освітній процес і проходить у вигляді вхідного контролю, проміжного контролю та підсумкового оцінювання результатів навчання, які формують фахову компетентність педагогів професійного навчання. Для цього визначаються критерії оцінювання та рівні підготовки та сформованості певних якостей майбутніх фахівців, а також розробляється діагностичний інструментарій, а саме: тестування теоретичних знань, аналіз та оцінювання результатів та об'єктів навчально-наукової діяльності; аналіз та оцінювання кваліфікаційного проекту та професійного портфоліо майбутніх педагогів професійного навчання.

Для реалізації кожного компонента системи обумовила потребу розробки освітньопрофесійних комплексів спеціальності 015 Професійна освіта (за спеціалізаціями), до яких входять стандарт вищої освіти спеціальності, освітня програма підготовки педагогів професійного навчання, навчальний план та пояснювальна записка до нього, опис навчальних дисциплін змісту підготовки майбутніх фахівців $[5,6,7,8,9,10,11,12]$.

Висновки. Для реалізації сучасної системи фахової підготовки педагогів професійного навчання, ціллю якої є підготовка компетентного фахівця здатного до професійно(інженерно)педагогічної діяльності у ЗПТ(П)О; здатного реалізувати себе в освітній сфері, на виробництві та у сфері обслуговування; фахівця майбутнього 3 неогуманістичними поглядами та сформованою екологічною культурою, нами запропоновано структурно-функціональну модель фахової підготовки на новій концептуально-методологічні основі. У подальших дослідженнях слід теоретично обгрунтувати та розробити науково-методичні матеріали, які дадуть можливість упровадити авторські розробки в практику фахової підготовки педагогів професійного навчання в університетах.

\section{ЛIТЕРАТУРА}

1. Бєляєв Ю. І. Науково-дослідна діяльність студентів у структурі роботи університету / Ю. І. Бєляєв, Н. М. Стеценко // Педагогічний альманах. - 2010. - Випуск 6. - с. 189, С. 188-191.

2. Гуменюк Т. Б. Професійна спрямованість природничо-наукової підготовки майбутніх педагогів професійного навчання. / Т. Б. Гуменюк, М. С. Корець. // Професійно-технічна освіта : науковометодичний журнал - К.: Вид-во "Педагогічна преса", 2016. - № 3 (72). - С. 38 - 41.

3. Гуменюк Т. Б., Корець М. С. Природничо-математична підготовка майбутніх педагогів професійнотехнічних навчальних закладів / Т. Б. Гуменюк, М. С. Корець. // Сучасні інформаційні технології та інноваційні методики навчання у підготовці фахівців: методологія, теорія, досвід, проблеми // Зб.наук.пр. - Випуск 44 / редкол. - Київ-Вінниця: ТОВ фірма «Планер», 2016. - 414 с., С.211 - 214.

4. Освітні технологіі: Навч.-метод. посіб. / О. М. Пєхота, А. З. Піктенко, О. М. Любарська та ін.; За ред. О. М. Пєхоти. - К.: А.С.К., 2004. - 256 с.

5. Освітньо-професійний комплекс: 015 Професійна освіта. Готельно-ресторанна справа: науковометодичне видання нормативних документів та змісту навчальних дисциплін, практик, курсових та випускної кваліфікаційної роботи щодо підготовки бакалаврів за спеціальністю 015 Професійна освіта (за спеціалізацією «Готельно-ресторанна справа»), галузь знань 01 Освіта/Педагогіка / Н. М. Зубар, Т. Б. Гуменюк, Н. М. Титова, А. А. Волкова - К.: Видавництво Національного педагогічного університету імені М. П. Драгоманова, 2017. - 173 с.

6. Освітньо-професійний комплекс: 015 Професійна освіта. Деревообробка: науково-методичне видання нормативних документів та змісту навчальних дисциплін, практик, курсових та випускної кваліфікаційної роботи щодо підготовки бакалаврів за спеціальністю 015 Професійна освіта (за спеціалізацією «Деревообробка»), галузь знань 01 Освіта / Педагогіка / А. В.Бровченко, Т. Б. Гуменюк, Н. М. Титова, І. В. Коваленко - К.: Видавництво Національного педагогічного університету імені М. П. Драгоманова, 2018. - 174 с. 
7. Освітньо-професійний комплекс: 015 Професійна освіта. Дизайн: науково-методичне видання нормативних документів та змісту навчальних дисциплін, практик, курсових та випускної кваліфікаційної роботи щодо підготовки бакалаврів за спеціальністю 015 Професійна освіта (за спеціалізацією «Дизайн»), галузь знань 01 Освіта / Педагогіка / Т. Б. Гуменюк, Н. М. Титова, I. В. Косяк, А. І. Шевченко - К.: Видавництво Національного педагогічного університету імені М. П. Драгоманова, 2017. - 181 с.

8. Освітньо-професійний комплекс: 015 Професійна освіта. Документознавство: науково-методичне видання нормативних документів та змісту навчальних дисциплін, практик, курсових та випускної кваліфікаційної роботи щодо підготовки бакалаврів за спеціальністю 015 Професійна освіта (за спеціалізацією «Документознавство»), галузь знань 01 Освіта / Педагогіка / Т. А. Жижко, Т. Б. Гуменюк, Н. М. Титова, О. О. Субіна - К.: Видавництво Національного педагогічного університету імені М. П. Драгоманова, 2017. - 192 с.

9. Освітньо-професійний комплекс: 015 Професійна освіта. Економіка: науково-методичне видання нормативних документів та змісту навчальних дисциплін, практик, курсових та випускної кваліфікаційної роботи щодо підготовки бакалаврів за спеціальністю 015 Професійна освіта (за спеціалізацією «Економіка»), галузь знань 01 Освіта / Педагогіка / О. Г. фон Будау, Т. Б. Гуменюк, Н. М. Титова, О. О. Субіна - К.: Видавництво Національного педагогічного університету імені М. П. Драгоманова, 2017. - 193 с.

10. Освітньо-професійний комплекс: 015 Професійна освіта. Технології виробів легкої промисловості: науково-методичне видання нормативних документів та змісту навчальних дисциплін, практик, курсових та випускної кваліфікаційної роботи щодо підготовки бакалаврів за спеціальністю 015 Професійна освіта (за спеціалізацією «Технології виробів легкої промисловості»), галузь знань 01 Освіта / Педагогіка / Т. Б. Гуменюк, Н. М. Титова, .В.Косяк, . С. Медведенко - К.: Видавництво Національного педагогічного університету імені М. П. Драгоманова, 2017. - 177 с.

11. Освітньо-професійний комплекс: 015 Професійна освіта. Туризм: науково-методичне видання нормативних документів та змісту навчальних дисциплін, практик, курсових та випускної кваліфікаційної роботи щодо підготовки бакалаврів за спеціальністю 015 Професійна освіта (за спеціалізацією «Туризм»), галузь знань 01 Освіта / Педагогіка / О. Г. фон Будау, Т. Б. Гуменюк, Н. М. Титова, М. М. Жеплінська - К.: Видавництво Національного педагогічного університету імені М. П. Драгоманова, 2018. - 174 с.

12. Освітньо-професійний комплекс: 015 Професійна освіта. Харчові технології: науково-методичне видання нормативних документів та змісту навчальних дисциплін, практик, курсових та випускної кваліфікаційної роботи щодо підготовки бакалаврів за спеціальністю 015 Професійна освіта (за спеціалізацією «Харчові технології»), галузь знань 01 Освіта/Педагогіка / Н. М. Зубар, Т. Б. Гуменюк, Н. М. Титова, А. А. Волкова - К.: Видавництво Національного педагогічного університету імені М. П. Драгоманова, 2017. - 174 с.

13. Пальчевський С. С. Педагогіка: підручник. - К.: Каравелла. - [Електронний ресурс]. - Режим доступу:http://pidruchniki.com/1169032835499/pedagogika/tehnologiya_pro ektnogo_navchannya].

14. Т. Б. Гуменюк Проектування фахівця майбутнього у процесі професійно-педагогічної підготовки в університеті ОСВІТНІЙ ДИСКУРС: Збірник наукових праць / Голов. ред. О. П. Кивлюк. - Київ: «Видавництво «Гілея», 2018. - Випуск 5 : гуманітарні науки. - 126 с., С.77 - 96. 